\title{
A Review of Modifiable Risk Factors in Young Women for the Prevention of Breast Cancer
}

This article was published in the following Dove Press journal:

Breast Cancer: Targets and Therapy

\author{
Alex A Daly (D) \\ Rachel Rolph ${ }^{2}$ \\ Ramsey I Cutress' \\ Ellen R Copson (D) $)^{\prime}$ \\ 'Cancer Sciences Academic Unit, Faculty \\ of Medicine, University of Southampton, \\ Southampton, SOI6 6YD, UK; \\ ${ }^{2}$ Department of Breast Surgery, Royal \\ Marsden Hospital, London, SW3 6JJ, UK
}

\begin{abstract}
Breast cancer is the most common cancer diagnosis in women aged less than 40 years and the second most common cause of cancer death in this age group. Global rates of young onset breast cancer have risen steadily over the last twenty years. Although young women with breast cancer have a higher frequency of underlying pathogenic mutations in high penetrance breast cancer susceptibility genes (CSG) than older women, the vast majority of young breast cancer patients are not found to have a germline CSG mutation. There is therefore a need to inform young women regarding non-genetic breast cancer risk factors which have the potential to be influenced by changes in individual behaviour. A Pubmed search was performed using the search terms "young" or "early onset", and "breast cancer" and "modifiable risk". Titles and abstracts from peer-reviewed publications were screened for relevance. This review presents evidence for potentially modifiable risk factors of breast cancer risk in young women, including lifestyle factors (physical activity, body habitus, alcohol use, smoking, shift work and socioeconomic factors), reproductive and hormonal factors and iatrogenic risks. The extent to which these factors are truly modifiable is discussed and interactions between genetic and non-genetic risk factors are also addressed. Health care professionals have an opportunity to inform young women about breast health and risk when presenting at a "teachable moment", including the benefits of physical activity and alcohol habits as risk factor. More focussed discussions regarding individual personal risk and benefit should accompany conversations regarding reproductive health and take into consideration both non-modifiable and iatrogenic BC risk factors.
\end{abstract}

Keywords: modifiable, risk factors, lifestyle, breast cancer, prevention, young

\section{Introduction}

Globally, breast cancer (BC) is currently the most common cancer diagnosed in women below the age of 40, accounting for 244,000 cases per year. ${ }^{1}$ It is also the second highest cause of cancer-related mortality in women aged 0-39 worldwide with 44,800 deaths per year. ${ }^{1}$ Women under the age of 45 account for $11 \%$ of all $\mathrm{BC}$ diagnoses in the United States (US) ${ }^{2}$ and $9 \%$ in the United Kingdom (UK). ${ }^{3}$ Furthermore, there has been a $16 \%$ increase in the incidence of $\mathrm{BC}$ in women aged 25-49 years since the 1990 s. $^{3}$

Geographically, the cumulative risk of developing BC varies between countries: the highest cumulative risk for women aged less than 40 years is seen in Italy and France $(0.9 \%)$, and lowest in India $(0.26 \%)$ with the UK and US having a moderate level of risk $\left(0.77 \%\right.$ and $0.61 \%$, respectively). ${ }^{1}$

Most young women are not eligible for asymptomatic breast screening and therefore present to clinicians with either personal breast symptoms or family-related
Correspondence: Ellen R Copson Somers Cancer Sciences Building, Southampton General Hospital, Tremona Road, Southampton, SOI6 6YD, UK

Tel +442381205170

$\mathrm{Fax}+442381205152$

Email E.Copson@soton.ac.uk
Breast Cancer: Targets and Therapy 2021:13 24I-257

submit your manuscript DovePress if in $v$ http://doi.org/10.2147/BCTTS26840/ 
concerns. Although young women with breast cancer have a higher frequency of underlying pathogenic mutations in high penetrance breast cancer susceptibility genes (CSGs) than older women, the vast majority of young breast cancer patients are not found to have a germline CSG mutation. ${ }^{4}$ Therefore, modifiable risk factors for breast cancer should also receive attention in this age group.

Clinician-patient interactions during a breast clinic consultation may provide unique opportunities to educate patients about modifiable cancer risk factors,: so-called "teachable moments" 5 These opportunities occur regardless of whether or not the patient receives a cancer diagnosis $^{6}$ and consultations pertaining to potential cancer diagnoses are regarded as "underused moments" for the provision of encouraging cancer risk-reducing behaviours. $^{7}$ When employing these moments to encourage behaviours that can reduce $\mathrm{BC}$ risk, the advice given should be based on a comprehensive understanding of the current evidence on modifiable lifestyle risk factors and how younger patients can most effectively influence their risk of disease.

This review presents current understanding of factors in young women associated with the development of primary $\mathrm{BC}$, the direction of risk and the magnitude of effect. Whilst previous publications in this area have focussed on life-style associated risk factors, this article also includes a discussion of the categorisation of risk factors and the inclusion of reproductive and iatrogenic factors as well as those factors that can be most influenced by an individual's behaviour. The interaction between modifiable and genetic factors is also considered.

\section{Methodology}

An electronic literature review using PubMed (NLM) was performed. Search terms included "young" or "early onset", and "breast cancer" and "modifiable risk". All identified articles published in English language between 1960 and 2020 were assessed for suitability. Abstracts and reports from meetings not published in peer-reviewed journals were excluded. Additional references known to the authors or cited within reference lists of relevant papers were also investigated. Articles were excluded from this review if they contained solely postmenopausal data or if they contained data for risk factors that were non-modifiable such as age, sex and past history of breast cancer or proliferative breast disease, apart from genetic risk factors which were included. The last search was performed in October 2020.

\section{Results}

\section{Defining "Young Women" in BC Research and Literature}

The European consensus treatment guidelines for $\mathrm{BC}$ in young women define "young" as aged 40 years or below ${ }^{8}$ partially based on the observation that women in this age group have poorer BC outcomes than older age groups. ${ }^{9}$ However, most epidemiological studies of $\mathrm{BC}$ risk, including the World Cancer Research Fund (WCRF) continuous update project, stratify patients according to menopausal status (pre- or postmenopausal).${ }^{10}$ Although in some datasets this categorisation is based on biological indicators of ovarian function, age ranges of $0-50$ or $0-55$ years are frequently used as surrogate indicators of premenopausal status. It is therefore evident that premenopausal groups will contain data for "young women" ( $\leq 40$ years), but will additionally include variable numbers of older women dependant on the data source. The biological differences in $\mathrm{BC}$ between age groups exist on a continuum so that a specific age threshold, such as below 40 years, alludes to trends in $\mathrm{BC}$ biology as opposed to definitive unique differences. ${ }^{11-13}$

\section{Categorising Risk Factors}

Many factors have been implicated as factors that influence $\mathrm{BC}$ risk in a younger female population, ${ }^{14}$ with variable effect sizes as well as variable degrees of modifiability.

Some factors associated with BC development are clearly "inherent" risk factors whereby an individual's choices cannot influence the risk factor, such as the germline genome or pre-natal development. Other risk factors are potentially "modifiable" such as: physical activity, body weight/habitus, alcohol consumption, which are influenced by personal choice. ${ }^{15}$

Some factors discussed in this review are more nuanced. For example, increased parity appears to decrease risk of developing $\mathrm{BC}$ but problems such as infertility may confound one's degree of personal choice over this factor. Iatrogenic risk factors are similarly more limited in terms of self-adjustment. These factors are referred to here as "less modifiable".

\section{Features of Young Onset Breast Cancer}

Women below the age of 40 with $\mathrm{BC}$ are more likely to die from the disease than older women., ${ }^{9,16,17}$ This can be explained in part by the biological characteristics of tumours in this cohort. 
BCs in young women have a higher frequency of more aggressive phenotypes than older women. Young patients are more likely to present with more advanced disease stage with larger tumour size, lymph node involvement, and less differentiated tumours. ${ }^{18-21}$ Tumour biology also reflects more aggressive disease in younger women with increased frequency of oestrogen receptor (ER) negative and triple negative tumours, ${ }^{11}$ and increased Ki-67 expression than in those over the age of 50 years. ${ }^{20,21}$

Women under 40 years at first breast cancer diagnosis have a higher frequency of a family history of BC and a higher chance of an underlying pathogenic mutation in a $\mathrm{BC}$ susceptibility gene than women diagnosed with breast cancer aged over 40 years. ${ }^{22} B R C A$ gene mutations (either $B R C A 1$ or $B R C A 2$ ) are found in approximately $12 \%$ of $\mathrm{BC}$ patients aged $<40$ years. ${ }^{4}$ TP53 germline mutations are found in $5 \%$ of diagnoses of $\mathrm{BC}$ aged $\leq 35$ years $^{23}$ and PALB2 mutations in approximately $1 \%$ in early-onset BC. ${ }^{24}$ Mutation penetrance seems to be higher in younger than older women for some breast cancer susceptibility genes (CSGs); the relative risk of developing $\mathrm{BC}$ was $8-9$ in $P A L B 2$ mutation carriers below 40 years compared to $5-8$ in women over 40 years. ${ }^{25}$

American studies have reported some notable racial variations in breast cancer age of onset, with black women experiencing significantly higher breast cancer incidence before the age of 40 years and lower incidence after age 50 compared with white women of the same ages. ${ }^{26}$ Differences in breast cancer incidence rates between most racial/ethnic groups have been largely explained by risk factor distribution except in African Americans ${ }^{27}$ where the higher incidence in the younger age group is not yet fully explained. Population-based studies in the UK have concluded that the younger age of Black Caribbean and Black African breast cancer patients in South East England reflects the younger age of these populations, rather than an increased risk of disease at younger ages ${ }^{28}$. Several non-age selected studies have reported increased incidence of adverse biological features in black women compared to white women. The POSH prospective study of 2915 breast cancer patients aged $<41$ years has confirmed this finding in young onset breast cancer with higher median tumour diameter and higher frequency of ER/PR/HER2-negative tumours in Blacks (26.1\%) than Whites $(18.6 \%, \mathrm{P}=0.04) .{ }^{29}$

\section{Modifiable Risk Factors Lifestyle Risk Factors \\ Physical Activity}

In the past, there had been a general acceptance that physical activity has no effect on premenopausal $\mathrm{BC}$ risk following large-scale prospective cohort studies such as Rockhill et al (104 468 participants) which reported no association. ${ }^{30}$ However, more recent data seem to contradict these findings. Since 2013, three independent meta-analyse ${ }^{31-33}$ investigating the effect of physical activity on premenopausal $\mathrm{BC}$ have concurred that physical activity significantly reduces the risk of premenopausal BC development. Physical activity led to a $23 \%$ reduction in $\mathrm{BC}$ cases (RR 0.77 ; $95 \%$ CI $0.72-0.84$ ) when comparing women in the highest versus the lowest categories of amounts and types of physical activity in a metaanalysis of 6 studies (2258 cases) ${ }^{31}$ Hardefeldt et al's 2018 meta-analysis of 48 cohort studies found that physical activitys ignificantly reduced overall risk (OR $0.79,95 \%$ CI $0.73-0.87)^{32}$ and finally Chen et al in 2019 reported an overall relative risk of 0.83 (95\% CI $0.79-0.87)$ over 14,968 cases, of developing premenopausal $\mathrm{BC}$ associated with physical activity. ${ }^{33}$ Therefore, it seems there is a recent body of evidence suggesting that physical activity may be key in reducing premenopausal BC risk.

\section{Intensity and Duration of Exercise}

Although evidence in premenopausal women is limited, it indicates a significant downward trend between increasing intensity (in metabolic equivalent task hours per week) and/ or longer duration (hours per week) of physical activity in relation to $\mathrm{BC}$ risk. ${ }^{34}$ For studies considering combined preand post-menopausal $\mathrm{BC}$ risk, for which there are significantly more data, the intensity of the exercise played a modest role in reducing risk. Engaging in "higherintensity" activities (activity that causes you to sweat, ie, running and competitive sports) had a slightly greater risk reduction (OR 0.73; 95\% CI 0.65-0.81; $\mathrm{P}<0.001$ ) than in those who did "low-intensity" activities (such as walking and gardening) (OR, 0.79; 95\% CI, 0.72-0.86; $\mathrm{P}<0.001){ }^{32}$ A meta-analysis of 11 studies reporting amount of exercise and 11 studies reporting metabolic equivalent task hours per week (MET-h/week) demonstrated a significant doseresponse relationship $(\mathrm{p}<0.0001)$ between increasing intensity and/or duration of exercise per week and reductions in $\mathrm{BC}$ risk. ${ }^{35}$ This method for reducing risk is especially important for a younger population, who tend to have an increased capacity for exercise; considering engaging in 
higher intensity exercises may be an effective way of significantly reducing their $\mathrm{BC}$ risk.

\section{Type of Exercise}

Chen et al's pooled analysis reported that overall relative risk reductions are associated with all types of physical activity (recreational, occupational and non-occupational) and the differences in risk between types of activity were modest. It remains unclear whether recreational physical activity specifically reduces risk in young women any more than occupational. ${ }^{36,37}$

\section{Adult Body Habitus/Body Mass Index}

It seems that physiological differences between pre- and postmenopause alter the effect of body mass index (BMI) on risk of developing $\mathrm{BC} .^{38}$ Younger adult women have a modest inverse correlation for BC risk with increasing BMI, according to many studies and meta-analyses (Table 1). ${ }^{39-46}$ This is contrary to the positive correlation between BMI and BC risk in post-menopausal women.

This relationship is comprehensively summarised in Renehan et al's meta-analysis of 20 prospective cohort studies, which reported that for every $5 \mathrm{~kg} / \mathrm{m}^{2}$ increase in $\mathrm{BMI}$ there was a significant decrease in relative risk of developing premenopausal BC (RR 0.92; 95\%
CI 0.88-0.97), highlighting a dose-response effect of BMI on premenopausal BC. ${ }^{39}$ The mechanism underpinning this effect is unclear and evidence limited, although it has been suggested that obesity causes ovarian suppression leading to decreasing levels of circulating oestradiol. ${ }^{47}$

BMI however is simply a marker of overall adiposity at a population level and does not inform us about the distribution of weight in the body in an individual. Waist-to-hip ratio (WHR) describes a pattern of adiposity (comparison of abdominal to gluteal fat), and increases in WHR are associated with increased risk of premenopausal BC. This was explored in a meta-analysis by Amadou et $\mathrm{al}^{42}$ that used 9 case-control and 3 cohort studies to demonstrate a significant dose-response premenopausal $\mathrm{BC}$ relative risk increase of 1.08 (95\% CI 1.01-1.16) per 0.1 unit increase in WHR, despite acknowledging that BMI was still associated with a significant doseresponse decreased relative risk of premenopausal $\mathrm{BC}$ per $5 \mathrm{~kg} / \mathrm{m}^{2}$ increase (RR 0.95;95\% CI 0.94-0.97). ${ }^{42}$ This suggests that although increases in BMI (as a marker of general adiposity) decrease risk, central adiposity (deposited around the abdomen) is associated with increased risk of premenopausal BC.

Furthermore, although a higher BMI is protective in premenopausal women, the magnitude of risk reduction in premenopausal $\mathrm{BC}$ is less than the increased $\mathrm{BC}$ risk

Table I Summary and Details of Meta-Analyses Investigating the Relationship Between BMI and Relative Risk (RR) of Developing Premenopausal BC

\begin{tabular}{|c|c|c|c|c|c|c|}
\hline Author and Year & $\begin{array}{l}\text { Study Type (Those } \\
\text { Included) }\end{array}$ & $\begin{array}{l}\text { Number } \\
\text { of Cases }\end{array}$ & $\begin{array}{l}\text { Menopausal } \\
\text { Status }\end{array}$ & $\begin{array}{l}\text { Age or Menopausal } \\
\text { Status Based } \\
\text { Studies? }\end{array}$ & BMI & $\operatorname{RR}(95 \% \mathrm{Cl})$ \\
\hline \multirow[t]{2}{*}{ Ursin et al $1995^{43}$} & \multirow{2}{*}{$\begin{array}{l}\text { Meta-analysis: } 4 \text { cohort } \\
\text { and } 19 \text { case-control } \\
\text { studies }\end{array}$} & \multirow[t]{2}{*}{ N/A } & \multirow[t]{2}{*}{ Premenopausal } & Age-based: 6 studies & \multirow[t]{2}{*}{$\begin{array}{l}\text { Per 8-unit } \\
\text { increase }\end{array}$} & $\begin{array}{l}\text { Cohort studies: } \\
0.70(0.54-0.91)\end{array}$ \\
\hline & & & & $\begin{array}{l}\text { Menopausal status } \\
\text { based: } 16 \text { studies }\end{array}$ & & $\begin{array}{l}\text { Case-Control } \\
\text { studies: } 0.88 \\
(0.76-1.02)\end{array}$ \\
\hline \multirow{2}{*}{$\begin{array}{l}\text { Van Den Brandt et al } \\
2000^{40}\end{array}$} & \multirow{2}{*}{$\begin{array}{l}\text { Meta-analysis: } 5 \\
\text { prospective cohort } \\
\text { studies }\end{array}$} & \multirow[t]{2}{*}{703} & \multirow[t]{2}{*}{ Premenopausal } & \multirow[t]{2}{*}{ Menopausal status } & $<21$ & 1.0 \\
\hline & & & & & $\geq 33$ & $0.58(0.34-1.00)$ \\
\hline Bergström et al $200 \mathrm{I}^{41}$ & $\begin{array}{l}\text { Meta-analysis: } 2 \text { cohort } \\
\text { and } 7 \text { case-control studies }\end{array}$ & 6533 & Premenopausal & N/A & $\begin{array}{l}\text { Per I-unit } \\
\text { increase }\end{array}$ & $0.98(0.97-0.99)$ \\
\hline Renehan et al $2008^{39}$ & Meta-analysis: 20 studies & 7930 & Premenopausal & N/A & $\begin{array}{l}\text { Per 5-unit } \\
\text { increase }\end{array}$ & $0.92(0.88-0.97)$ \\
\hline Amadou et al $2013^{42}$ & $\begin{array}{l}\text { Meta-analysis: II cohort } \\
\text { and I } 8 \text { case-control } \\
\text { studies }\end{array}$ & 14,429 & Premenopausal & $\begin{array}{l}\text { Age and menopause } \\
\text { status based }\end{array}$ & $\begin{array}{l}\text { Per 5-unit } \\
\text { increase }\end{array}$ & $0.95(0.91-0.98)$ \\
\hline
\end{tabular}


witnessed post-menopause. ${ }^{39}$ Many studies agree that weight change during adulthood increases the risk of $\mathrm{BC}$ at an older age (post-menopausal). ${ }^{48-51}$ Although true that a higher $\mathrm{BMI}$ can reduce $\mathrm{BC}$ risk in premenopausal women, the cumulative risk of developing $\mathrm{BC}$ across a person's lifetime will be increased in those with a high BMI. ${ }^{38}$ Obesity is also associated with increased risk of other malignancies and other serious health issues. Therefore, gaining weight should not be recommended as a suitable method to reduce $\mathrm{BC}$ risk long term. Interestingly, in the Carolina Breast Study, higher adult body mass index was inversely associated with premenopausal breast cancer for Whites but not for Blacks; ${ }^{52}$ Higher waist/hip ratio, adjusted for body mass index, increased risk for both black and white premenopausal women. $^{53}$

\section{Alcohol}

Swanson et al investigated the effect of alcohol consumption in young women ( $<45$ years) in 1997 , and found that those who drank more than 14 alcoholic drinks per week had the highest risk of developing BC (RR 1.73, 95\% CI 1.2-2.6) compared with non-drinkers. ${ }^{54}$

Since then, many studies have investigated the effect of alcohol consumption on $\mathrm{BC}$ and most have found that alcohol increases risk of $\mathrm{BC}$ in young or premenopausal women. ${ }^{55-57}$

In their evaluation of evidence in 2018, the WCRF concluded that there was "strong probable" evidence that alcohol consumption increases the risk of premenopausal BC. A pooled multivariate analysis of 3730 cases of premenopausal women found that a $10 \mathrm{~g}$ per day increment of alcohol consumption was associated with a BC RR of 1.03 (95\% CI: 0.99-1.08), thus supporting the idea that a dose-response effect exists between alcohol and risk of premenopausal BC. ${ }^{58}$ This supports the WCRF meta-analysis which found statistically significant evidence of dose-response relationship between alcohol and premenopausal BC risk, whereby an increase of $10 \mathrm{~g}$ of ethanol per day led to a 5\% increased risk of developing $\mathrm{BC}$ in premenopausal women. ${ }^{10}$

Type of alcohol beverage also appears to be significant when considering premenopausal BC risk. The WCRF's 2018 report concluded that consuming $10 \mathrm{~g}$ of ethanol per day as beer had a RR of 1.32 (95\% CI: 1.06-1.64) whereas from wine this was less (RR 1.17, 95\% CI: $0.79-1.73$ ) and from spirits the lowest (RR 1.10, 95\% CI: 0.92-1.30). ${ }^{10}$

\section{Smoking}

The impact of active smoking on BC risk in young women has been unclear since it was first discussed by MacMahon in 1982. ${ }^{59-61}$ The Collaborative Group on Hormonal Factors in BC's meta-analysis showed that the effect of smoking on $\mathrm{BC}$ risk is confounded by its known association with alcohol. ${ }^{61,62}$ However, most research concurs that if there is a risk associated with smoking, that it is more influential in premenopausal (than post-menopausal) BC risk. ${ }^{63-65}$ Women who commence smoking at a young age seem to have a higher lifetime $\mathrm{BC}$ risk than those who take up smoking in later life. A cohort study of 1815 women with invasive $\mathrm{BC}$ found that the hazard ratio for all "ever" smokers (compared to never smokers) was 1.14 (95\% CI 1.03-1.25; $\mathrm{p}=0.010)$ rising to 1.24 (95\% CI 1.$08-1.43 ; \mathrm{p}=0.002$ ) for starting smoking at ages $<17$ years. $^{66}$

Interestingly, passive smoking may be a greater risk factor for $\mathrm{BC}$ than active smoking. It has been postulated that active smoking is associated with an anti-oestrogenic effect which may to some extent counteract exposure to smoking-related carcinogens. Passive smoking does not "benefit" from the anti-oestrogenic effect but results in continued exposure to carcinogenic compounds (ie, $\mathrm{N}$-nitrosamines, benzenes, carbon monoxide and carbon dioxide) which persist in side stream smoke and therefore, a relatively increased risk of breast oncogenesis. ${ }^{64,67,68}$ A meta-analysis including 14 studies of smoking and premenopausal BC risk found that passive smoking was associated with an increased risk (pooled RR 1.68, 95\% CI 1.88-2.12) increasing to a pooled summary risk estimate of 2.19 (95\% CI 1.68-2.84) when the analysis was limited to the 5 studies with more complete exposure data. ${ }^{63}$

Individual studies place emphasis on genetic susceptibility and how this, compounded with exposure to secondary smoke, greatly increases $\mathrm{BC}$ risk $^{64,69}$ For example, one study found that passive smoke exposure increased premenopausal BC risk in PARP1 or ESR1 genetically susceptible individuals (OR 1.54 95\% CI 1.14-2.07). ${ }^{69}$

\section{Other Lifestyle Factors \\ Night Shift Work}

Long-term rotating night shift work in young adulthood is particularly associated with increased risk of ever developing $\mathrm{BC}$ according to an analysis of two largescale prospective cohort studies $(n=9541$ total invasive BCs) in the United States: The Nurses' Health study (NHS) and Nurses' Health study II (NHS-II). ${ }^{70}$ This 
analysis found that in the NHS, women who had done 30 years or more of shift work did not have a higher risk of breast cancer (HR 0.95; 95\% CI 0.77-1.17) compared with those who had never done shift work. However, participants of the NHS-II, who were a younger cohort (by approximately 20 years) than those in NHS had a significantly higher risk of breast cancer with 20 years or more of shift work $(\mathrm{HR}=2.15,95 \%$ CI 1.23-3.73), and a significantly higher risk for women with 20 years or more of cumulative shift work ( $\mathrm{HR}=1.40$; 95\% CI 1.00-1.97) compared to those who had never done shift work. ${ }^{70}$ This conclusion is supported by a Spanish case-control study (OR 1.08; 95\% CI 0.98-1.79) ${ }^{71}$ which found that night shift work was a higher risk factor in premenopausal than post-menopausal BC.

Shernhammer et al found that there was a nonsignificant increase in premenopausal $\mathrm{BC}$ relative risk with number of years on rotating night shift work, and that the risk of developing premenopausal breast cancer appeared to increase with increasing years on a rotating night shift ("Never" worked a night shift age adjusted RR: 1.0 ; "1-14 years" RR 1.23, 95\% CI 0.98-1.56); " $\geq 15$ years" RR: $1.30,95 \%$ CI $0.75-2.26) .^{72}$

A recent pooled analysis by Coridina-Duverger et $\mathrm{al}^{73}$ using studies from 5 different "western" countries: Australia, Canada, France, Germany and Spain found that there was a pooled odds ratio of developing premenopausal BC of 1.26 (95\% CI 1.06-1.51) associated with having "ever" worked a night shift for 3 or more hours between midnight and 5am. This risk increased to 2.55 (95\% CI 1.03-6.30) for those who had been working the most night shifts per week ( 3 or more per week) and for a longer period of time ( $>10$ years).

Working at night causes disruptions in circadian rhythm, whereby the "light-at-night" causes a suppression of pineal gland production of the hormone melatonin. ${ }^{74}$ Pre-clinical trials suggest that melatonin exerts tumour-suppressive effects through a variety of mechanisms, including modulation of the oestrogen pathway, producing an anti-oestrogenic effect. Therefore, it is hypothesised that the absence of melatonin can lead to breast tumour growth. ${ }^{75}$

\section{Socioeconomic Status (SES)}

Globally in 2020, the highest incidence rates for premenopausal BC occur in high human development index (HDI) regions (such as Western Europe, Australia and New Zealand and North America), however low human development index regions (such as North and West Africa) had higher new cases and mortality with premenopausal BC in proportion to those of higher income. ${ }^{76}$

There is a lack of data for the impact of SES within a young US population. However, Akinyemiju et $\mathrm{al}^{77}$ looked at SES across different ethnicities in a US population and found that combined early and late BC risk increased with increasing socioeconomic status. This shows concordance with current understanding of this relationship whereby women of higher socioeconomic status are at the highest risk of developing $\mathrm{BC}$ but have better survival outcomes from their diagnoses than lower-income areas in the US. ${ }^{78}$

An analysis of data from the Wisconsin longitudinal study (4275 women) found that having a higher socioeconomic status (SES) in early life/childhood and being born of a mother of a higher educational level increased $\mathrm{BC}$ incidence. ${ }^{79}$ The underlying reasons may be that higher SES individuals tend to be older at the age of their first pregnancy and have decreased parity compared with lower SES. ${ }^{79,80}$

\section{Lifestyle Factors Conclusions}

The evidence suggests that physical activity reduces the risk of premenopausal and early onset breast cancer with a dose-dependent effect and for all types of activity and so should be recommended. In contrast, although there is a slight risk reduction seen for premenopausal breast cancer with increased BMI this is offset both by the larger increased risk for post-menopausal breast cancer and the more general and cardiovascular risks of obesity and so maintaining a healthy weight, BMI and body composition should be recommended. Alcohol is perhaps one of the more easily modifiable risk factors and there is a dosedependent relationship with breast cancer risk so should be reduced wherever possible. The effects of smoking may be confounded by alcohol intake but should be avoided regardless due to the overall harm to health beyond that of breast cancer alone. Socioeconomic status and shift working patterns are less easily modifiable and are perhaps more easily addressed at a public health and population rather than individual level.

\section{Reproductive Risk Factors}

Within high-income countries, there has been a shift in reproductive behaviours, favouring fewer children per household and at a later stage in a woman's reproductive timeframe. Simultaneously, there has been an increased 
uptake in the use of exogenous hormonal medications, in the form of the oral contraceptive pill (OCP), intrauterine hormonal devices and menopausal hormone therapy (MHT), as cultural shifts have occurred within society. ${ }^{81}$ Epidemiological evidence associates both exogenous and endogenous hormone exposure with an increased risk of $\mathrm{BC}^{82}$ with exogenous hormone use being amenable to risk modification. There are two types of oestrogen (conjugated equine oestrogen and oestradiol) and four types of progestogen (norethisterone acetate, levonorgestrel, medroxyprogesterone, and dydrogesterone) commonly prescribed in the UK. ${ }^{83}$

\section{Hormonal Contraceptives}

In 2018, the OCP was the main method for contraception for $28 \%$ of women in the UK and was the most common method used by women aged between 15 and 49 years. $^{84}$

In 1996, a large collaborative dataset confirmed the association of an increased risk of BC with OCP use. This analysis compared OCP use in 53,297 women with $\mathrm{BC}$ and 100,239 women without a $\mathrm{BC}$ diagnosis and concluded an overall relative risk (RR) of BC in OCP users of $1.24(95 \%$ CI 1.15-1.33). ${ }^{85}$ On stopping the OCP the modest increased risk disappeared after 10 years (RR 1.01 95\% CI 0.96-1.05). In real terms, this equates to one additional $\mathrm{BC}$ case with OCP use among 20,000 women aged 20-25 years using this form of contraception. ${ }^{82}$ For women with a higher background risk, such as strong family history or high risk genetic mutation carriers, the data are limited but suggest the same effect in $\mathrm{BC}$ risk as for the overall population. ${ }^{82} \mathrm{~A}$ more recent Danish paper has shown that the duration of contraceptive pill use to be important, with 13 years use associated with the highest increase of relative risk at $18 \%$ compared to a 5\% RR increase for five years use. ${ }^{86}$ Mørch et al calculated an overall $\mathrm{BC}$ risk with users of any hormonal contraceptive to be one extra BC case for every 7690 women using hormonal contraception for 1 year. Long-term hormonal contraceptive use has not been found to be associated with increased total cancer risk however. ${ }^{87}$ As the overall population risk for $\mathrm{BC}$ in women in their $20 \mathrm{~s}$ is low, the absolute risk for BC with OCP use is therefore small $(1: 20,000)$. In an older cohort of women (over 35 years old), with increased overall risk including family history, the additional increased $\mathrm{RR}$ with age with the OCP use is an important consideration. Long-term follow-up data on women using the OCP have shown a considerable protection against cancer of the ovary $(\mathrm{RR}=0.67)$, endometrium $(\mathrm{RR}=0.66)$, or colorectum $(\mathrm{RR}=0.81) .{ }^{88}$ Physicians need to establish a risk-benefit ratio on an individual basis to enable a joint decision between the physician and patient on the use of hormonal contraception. For example, patients with $B R C A 1$ mutations will be at potentially increased risk of $\mathrm{BC}$ with OCP use, versus a protective effect for ovarian cancer risk should they not be planning a risk-reducing oophorectomy. ${ }^{89}$

An increased risk has also been noted with the progestin-only intrauterine system (levonorgestrel-releasing intrauterine system (LNG-IUS, Mirena ${ }^{\circledR}$ )) compared to women who had not used hormonal contraceptives (RR $1.21 ; 95 \%$ CI 1.11 to 1.33$){ }^{86}$

The use of a LNG-IUS is often informed by the need to control heavy menstrual bleeding and avoidance of gynaecological procedures. A recent systematic review and meta-analysis on LNG-IUS users concluded an overall increased risk of $\mathrm{BC}$ for all users (odds ratio $\mathrm{OR}=1.16$; 95\% CI 1.06-1.28) with an increased risk in women over 50 years $(\mathrm{OR}=1.52(95 \% \mathrm{CI} 1.34-1.72)) .{ }^{90} \mathrm{~A}$ risk-benefit discussion between gynaecologist and patient, taking into account personal $\mathrm{BC}$ risk factors, is recommended prior to commencement of this long-term hormonal treatment.

\section{Menopausal Hormonal Therapy}

Premature menopause before the age of 40 (in the absence of treatment for cancer) is rare affecting $1 \%$ of women. ${ }^{91}$ However, the adverse impact of menopausal symptoms on quality of life in women with premature menopause is well documented and exogenous hormonal replacement therapy (HRT; or menopausal hormonal therapy MHT) is frequently recommended for their relief and also sometimes for bone protection purposes. There are predominately two main forms of preparations: unopposed oestrogen therapy and combined oestrogen and progestin preparations. ${ }^{82}$

A large meta-analysis of worldwide epidemiological evidence for type and timing of MHT and BC risk was published in the Lancet in 2019. ${ }^{92}$ This study did include women aged 30-39 but there were insufficient data to analyse the impact on breast cancer risk associated with use of MHT for $<5$ years in this age group. Current use of MHT for 5-15 years starting between ages of 30-39 was not overall found to be associated with a statistically significant increased risk (RR 1.07; 95\% CI 0.88-1.31) associated with a RR of 1.07 (95\% CI 0.88-1.31).

The UK National Institute for health and Care Excellence (NICE) guidelines for patients with a familial $\mathrm{BC}$ risk recommend tailoring of MHT to individual needs and seeking alternatives to MHT where possible. MHT should generally be prescribed at the 
lowest dose required to control symptoms and for as short a duration as possible. ${ }^{89}$ However, when women with no personal history of breast cancer have either a $B R C A 1$ or $B R C A 2$ mutation or a family history of breast cancer and they have had a bilateral salpingo-oophorectomy before their natural menopause, they can be offered either combined HRT if their uterus remains or oestrogen-only HRT if their uterus has been removed, up until the time they would have expected natural menopause (average age for natural menopause is $51-52$ years). ${ }^{89}$

\section{Fertility Enhancement and Preservation Techniques}

Women who decide to have children later in life may undergo fertility techniques for oocyte harvesting, oocyte cryopreservation and embryo transfer techniques and fertilisation (In vitro fertilisation (IVF)). Follicle-stimulating hormone (FSH) injections are often used daily for 2 weeks to stimulate follicle development and assist harvesting. No association has been reported between use of fertility preservation techniques and $\mathrm{BC}$ development, ${ }^{82}$ including for BRCA 1/2 mutation carriers. IVF exposure was not associated with risk of BC (HR: 0.79, 95\% CI: 0.46-1.36). ${ }^{93}$ A recent systematic review has highlighted however there is limited evidence on the association between IVF and premenopausal breast cancer risk. ${ }^{94}$

\section{Pregnancy and Parity}

The age at which a woman gives birth to a child has been shown to influence her $\mathrm{BC}$ risk. ${ }^{81}$ Arguably, timing of pregnancy and child-bearing is not always planned, however a woman with an increased $\mathrm{BC}$ risk may wish to actively start a family earlier to reduce her $\mathrm{BC}$ risk. The age at first pregnancy is especially important, with parity under 20 years of age associated with the longest term risk reduction of $50 \%$ compared to nulliparous women. ${ }^{95}$ Having a child over 35 years of age conferred an increased BC risk compared to a nulliparous woman. ${ }^{96}$ Recent data suggest that the age of first pregnancy and parity affects the risk of specific BC subtype development, with young age of first pregnancy and parity being associated with a reduction in luminal oestrogen receptor positive BCs but not other subtypes. ${ }^{97}$

Post-partum there is a transient observed increase in $\mathrm{BC}$ risk which is attributed to the post-partum involution process within the breast. ${ }^{81}$ It is hypothesised that the breast remodelling following lactational changes takes up to ten years on average and the increased risk may be due to immune microenvironment changes. ${ }^{81}$ The reduction in $\mathrm{BC}$ risk following this period may be due to a reduction in ER sensitive epithelial cells within the breast. $^{98}$ Compared to nulliparous women, parous women have an increased $\mathrm{BC}$ risk peaking 5 years after birth before decreasing up to 34 years later (HR, 1.80 [95\% CI, 1.63 to 1.99$]$ ) and 0.77 (CI, 0.67 to 0.88 , respectively). ${ }^{99}$

Data from the 1993-2001 Carolina Breast Cancer Study which included 1505 African-American and 1809 White women identified some important racial differences in breast cancer risk factors amongst younger women (aged 20-49). Multiparity was associated with increased risk of breast cancer among younger African-American women (for three or four pregnancies: adjusted odds ratio $(\mathrm{OR})=1.5,95 \%$ confidence interval $(\mathrm{CI}): 0.9,2.6$; for five or more pregnancies: $\mathrm{OR}=1.4,95 \% \mathrm{CI}$ : $0.6,3.1$ ) but not among younger White women (for three or four pregnancies: $\mathrm{OR}=0.7,95 \% \mathrm{CI}$ : $0.4,1.2$; for five or more pregnancies: $\mathrm{OR}=0.8,95 \% \mathrm{CI}: 0.2,3.0$ ). The relationship with age at first full-term pregnancy and nulliparity also varied by race. ${ }^{100}$ Thus, the higher incidence of breast cancer among younger African-American women may result from both higher prevalence of risk factors and higher relative risks associated with these.

\section{Breastfeeding}

Breastfeeding has been shown to reduce a woman's risk of BC. ${ }^{101}$ The mechanism of risk reduction is not clear; however, for every 12 months of breast feeding, the RR reduction is $4 \%$ for all women with an increased $\mathrm{RR}$ reduction of $5.1 \%$ for premenopausal BC. ${ }^{81,102}$

Interestingly, the protective effect of breast feeding is not limited to only hormone receptor positive breast cancer subtypes. ${ }^{103}$ A reduction in risk has also been demonstrated in hormone receptor negative breast cancers which are more common in younger women. ${ }^{104}$

The World Health Organisation recommends at least six months of breast feeding post-partum prior to weaning for a protective effect. ${ }^{105}$ Young mothers should be supported to breastfeed to reduce their $\mathrm{BC}$ risk in addition to promoted benefits to the developing baby.

\section{Risk-Reducing Medications}

Anti-oestrogen medications may be offered in specialist clinics to women with high and moderate personal risk for $\mathrm{BC} .{ }^{106}$ These medications are referred to as "chemoprevention" however risk-reducing medication is a more favourable term to encourage uptake. ${ }^{81}$ 
In premenopausal women, use of tamoxifen for 5 years reduced $\mathrm{BC}$ risk by $33 \%$ and the reduction persisted for at least 15 years after cessation of the anti-hormonal medication. ${ }^{107,108}$ Of note, there was no benefit shown for overall $\mathrm{BC}$ mortality with this treatment. They may be a useful option for women with high to moderate risk of $\mathrm{BC}$ who wish to reduce their risk as an alternative or bridge to risk-reducing surgery. ${ }^{106}$ Caveats to the use of tamoxifen are an increased risk of venous thromboembolism and endometrial cancer (risk 4:1000). A short trial of tamoxifen for six to eight weeks may feel more acceptable to a patient prior to a five-year course to test for medication induced side effects. ${ }^{81}$ Although raloxifene and aromatase inhibitors have been shown to reduce breast cancer occurrence in high risk post-menopausal women, these drugs are not recommended in premenopausal women. ${ }^{89}$ Non-hormonal forms of chemoprophylaxis for breast cancer remain under investigation. Several meta-analyses of observational studies have reported reduced risk of breast cancer in aspirin users compared to non-users. ${ }^{109,110}$ However, in their subgroup analysis, Cao et al found a significant risk reduction of breast cancer associated with aspirin use in postmenopausal women $(\mathrm{RR}=0.89,95 \%$ CI: $0.83-0.96, P$ $=.002)$, but not in premenopausal women $(\mathrm{RR}=0.88$, 95\% CI: $0.72-1.08, P=.223) .{ }^{110}$

\section{Reproductive and Hormonal Factors Conclusions}

In younger women less than the age of 35 the absolute increased breast cancer risk with the combined oral contraceptive is very small and so this can be prescribed with appropriate information. Between the age of 35 and 50 women with a breast cancer family history should be aware that the increased breast cancer risk increases with age as their absolute familial breast cancer risk increases and this should be weighed within the overall risks and benefits of the combined oral contraceptive. For those with $B R C A 1$ or $B R C A 2$ gene alterations considering the combined oral contraceptive the situation is more complex and specialist genetic service input may be beneficial to judge the competing impacts of increased breast cancer risk against reduced ovarian cancer risk within the specific circumstances of the individual. ${ }^{111}$ For those with an early menopause no increased risk is seen with HRT up to the natural age of menopause for a general population, but in those with increased familial risk more specialist input may again be helpful.

\section{latrogenic Risk Factors \\ Breast Implants}

Worldwide it is estimated that over 1.8 million breast augmentation procedures are performed annually, of which $2.8 \%$ are in those aged 18 years or younger, $53.9 \%$ in those aged 19-34 and 35.0\% in those aged 35-50. The UK independent review group on Silicone Gel Breast Implants concluded that $\mathrm{BC}$ incidence is not raised in women with breast implants, ${ }^{112}$ however, in those with cosmetic breast augmentation breast cancer diagnosis appears to occur at a later stage and possibly impacts negatively on survival. ${ }^{113}$ More recently an association has been identified between silicone breast implants and a form of non-Hodgkin lymphoma known as Breast implant-associated anaplastic large cell lymphoma (BIA-ALCL). This typically occurs 7-10 years following implantation, ${ }^{114}$ and so given the demographics of cosmetic breast augmentation surgery will be relevant to younger women considering such surgery. The MHRA estimates that the incidence of the BIA-ALCL is 1 per 20,000 implants sold, ${ }^{115}$ and since cosmetic augmentation is usually a bilateral procedure, the rate may be 1 per 10,000 in women undergoing cosmetic implant breast augmentation.

\section{Treatment of Hodgkin Lymphoma (HL)}

It has been recognised since the 1980s that treatment for Hodgkin's Lymphoma (HL) is associated with a subsequent increased risk of $\mathrm{BC}$ amongst other secondary malignancies, with an increasing risk over time for over three decades after HL diagnosis. A recent study of 200945 survivors of teenage and young adult cancer survivors reporting cumulative risk of $\mathrm{BC}$ of $0.3 \%, 1.3 \%$, $3.8 \%, 6.7 \%, 10.8 \%$ and $14.4 \%$ at $10,15,20,25,30$ and 35 years after $\mathrm{HL}$ diagnosis. ${ }^{116}$ Risk of $\mathrm{BC}$ in HL survivors is closely associated with use of mantle irradiation with both total dose and field size/site of irradiation influencing risk levels. ${ }^{117} \mathrm{~A}$ significantly lower risk of $\mathrm{BC}$ has been reported among patients who received supradiaphragmatic field radiotherapy not including the axilla than among those who received complete mantle-field radiotherapy (HR, 0.37; 95\% CI 0.19 to 0.72 ). ${ }^{118}$ Recognition of these risk factors led to adoption of potentially less toxic treatment regimes in the late 1980s incorporating smaller and less intense radiation fields. However, recent cohort studies comparing second malignancy rates in patients treated for HL during different time periods have not indicated the anticipated fall in treatment-related $\mathrm{BC}$ rates with newer treatment regimens. ${ }^{118,119}$ It is postulated that this is due to the simultaneous adoption of less toxic 
chemotherapy regimens with a lower incidence of premature menopause with associated reduction in oestrogen exposure.

Age at time of HL diagnosis is an important modifier of risk. Studies of childhood cancer survivors however indicate that radiation treatment at age $10-16$ years carries more risk than treatment at age $<10$ (RR 1.9). ${ }^{117}$ In the teenage and young adult (TYA) population RR is significantly higher for those treated for HL at age $<19$ than those treated at 20-29 years with no increased BC risk for HL patients diagnosed at $\geq 30$ years. ${ }^{120}$

For women who received radiotherapy for HL between the ages of 10-29, current UK guidelines recommend that breast screening in the form of an annual magnetic resonance imaging (MRI) scan should start 8 years after radiotherapy to breast tissue or at age 25 or 30 (whichever occurs later). Women treated between the ages of 30-39 should commence annual breast MRIs at age $30 .{ }^{121}$

\section{Interactions Between Genetic and Modifiable Risk Factors for Young Breast Cancer}

Female HL patients with a family history of $\mathrm{BC}$ are significantly more likely to develop $\mathrm{BC}$, compared to $\mathrm{HL}$ patients with no history of $\mathrm{BC}$ among relatives. ${ }^{119,122}$ However, there is currently no evidence that there is a role for mutations in the known high penetrance $\mathrm{BC}$ susceptibility genes TP53, BRCA1, BRCA2, and ATM as a cause of subsequent cancer risk in HL survivors. ${ }^{123}$

Some studies report that there are important interactions between an individual's genetics (their background risk) with lifestyle risk factors that can alter the effect size or direction of risk. Niehoff et al demonstrated that recreational physical activity does not reduce risk in premenopausal women with a family history of $\mathrm{BC},{ }^{124}$ contrary to the effect seen in young women without familial history.

Tryggvadottir et $\mathrm{al}^{125}$ investigated the changes in risk of developing any $\mathrm{BC}$ associated with $B R C A 2$ mutations in an Icelandic population, reporting that there was a fourfold increase of incidence of $\mathrm{BC}$ in BRCA2 mutation carriers in 2000 (compared to 1920), ultimately concluding that $B R C A 2$ mutation penetrance has increased with time. This work concluded that this increase in penetrance was proportional to increases in the Icelandic population of modifiable $\mathrm{BC}$ risk factors which have increased over time. Additionally, a case-control study by Jernström et al showed that young women (below age 40 years) who carried BRCA1 and BRCA2 mutations would be at higher risk of developing $\mathrm{BC}$ with increasing number of pregnancies. Therefore, the direction of a partially modifiable risk factor such as parity is dependent on whether they have wild type or mutant $B R C A 1$ and 2 genes. ${ }^{126}$ Tobacco smoking in BRCA1 and 2 mutation carriers increases risk of developing $\mathrm{BC}$ by $17 \%$ compared to mutant non-smokers, and women with the highest pack years (4.3-9.8) having a $33 \%$ increase of $\mathrm{BC}(\mathrm{HR}=1.33$ $9 \%$ CI $1.02-1.75) .{ }^{127}$ More research is needed the investigate the interactions between genetic effects and other factors.

Counselling and health education for premenopausal women with a family history of $\mathrm{BC}$ is complex. Communicating DNA-based disease risk estimates for conditions where risk could be reduced by behaviour change produced no significant effects on smoking, diet, physical activity or alcohol use behaviours. ${ }^{128}$ An interview study of premenopausal women with a family history of $\mathrm{BC}$ who were overweight/obese found that they had feelings of guilt and anxiety when unable to lose weight. Therefore, credible rationales for weight loss that address these feelings of anxiety and doubt are required to reduce this significant risk factor in this high risk population, as well as appropriate support. ${ }^{129}$ In a feasibility study of 79 overweight premenopausal women at increased risk of breast cancer, $55 \%$ of those enrolled in a 12 -month diet and exercise weight loss programme $(n=40)$ achieved target weight loss of $5 \%$ baseline weight, compared to $15 \%$ of those receiving usual care in the form of a healthy lifestyle advice leaflet. ${ }^{130}$

\section{Conclusions}

$\mathrm{BC}$ is the most common cancer diagnosis in women aged under 40 and associated with poorer survival outcomes than in older women. As incidence of young onset BC increases globally there is an urgent need to address risk factors that are modifiable by individual behaviour change.

Overall risk is however determined by both modifiable and non-modifiable risk factors and the most significant nonmodifiable risk factor is often familial risk. Health care professionals should therefore assess $\mathrm{BC}$ inherent and familial risk through a careful medical and family history and aim to discuss modifiable factors in relation to this background risk. Modifiable risk factors (Table 2) including physical activity and alcohol habits should be considered whenever presented with a "teachable moment" applicable to breast health. Discussions regarding personal risks and benefits 
Table 2 Summary of the Key Evidence Regarding Specific Risk Factors in Relation to the Risk of Developing Breast Cancer at a Premenopausal Age/Stage

\begin{tabular}{|c|c|c|c|c|c|}
\hline $\begin{array}{l}\text { Risk } \\
\text { Factor }\end{array}$ & $\begin{array}{l}\text { Author and } \\
\text { Year }\end{array}$ & Type of Study & $\begin{array}{l}\text { Effect on Risk of } \\
\text { Premenopausal } \\
\text { Breast Cancer }\end{array}$ & Comparator & Magnitude of Risk $(95 \% \mathrm{Cl})$ \\
\hline \multicolumn{6}{|c|}{ Physical Activity } \\
\hline & Wu et al $2013^{31}$ & Meta-analysis & Reduced & $\begin{array}{l}\text { "Highest" vs. "lowest" } \\
\text { categories of amount of } \\
\text { physical activity }\end{array}$ & RR $0.77(0.72-0.84)$ \\
\hline & $\begin{array}{l}\text { Hardefeldt et al } \\
2018^{32}\end{array}$ & Meta-analysis & Reduced & $\begin{array}{l}\text { Effect of "any" exercise } \\
\text { intervention vs. "none" }\end{array}$ & OR $0.79(0.73-0.87)$ \\
\hline & $\begin{array}{l}\text { Chen et al } \\
2019^{33}\end{array}$ & Meta-analysis & Reduced & $\begin{array}{l}\text { Effect of "any" exercise } \\
\text { intervention vs. "none" }\end{array}$ & RR $0.83(0.79-0.87)$ \\
\hline \multicolumn{6}{|l|}{ BMI } \\
\hline & \multirow[t]{2}{*}{$\begin{array}{l}\text { Ursin et al } \\
1995^{43}\end{array}$} & \multirow[t]{2}{*}{ Meta-analysis } & \multirow[t]{2}{*}{ Reduced } & \multirow[t]{2}{*}{$\begin{array}{l}\text { Per 8- unit increase in } \\
\text { BMI }(\mathrm{kg} / \mathrm{m} 2)\end{array}$} & $\begin{array}{l}\text { Cohort Studies: RR } 0.70 \\
(0.54-0.91)\end{array}$ \\
\hline & & & & & $\begin{array}{l}\text { Case-control studies: RR } 0.88 \\
(0.76-1.02)\end{array}$ \\
\hline & $\begin{array}{l}\text { Renehan et al } \\
2008^{39}\end{array}$ & Meta-analysis & Reduced & $\begin{array}{l}\text { Per } 5 \text {-unit increase in } \\
\mathrm{BMI}(\mathrm{kg} / \mathrm{m} 2)\end{array}$ & RR $0.92(95 \% \mathrm{Cl} 0.88-0.97)$ \\
\hline & $\begin{array}{l}\text { Amadou et al } \\
2013^{42}\end{array}$ & Meta-analysis & Reduced & $\begin{array}{l}\text { Per } 5 \text { - unit increase in } \\
\text { BMI }(\mathrm{kg} / \mathrm{m} 2)\end{array}$ & RR 0.95 (95\% Cl 0.9I-0.98) \\
\hline \multicolumn{6}{|l|}{ Alcohol } \\
\hline & Jung et al $2016^{58}$ & Meta-analysis & Increased & $\begin{array}{l}\text { Per I0g ethanol per day } \\
\text { increase }\end{array}$ & RR I.03 (95\% Cl 0.99-1.08) \\
\hline & $\begin{array}{l}\text { WCRF Report, } \\
2018^{10}\end{array}$ & Meta-analysis & Increased & $\begin{array}{l}\text { Per } 10 \mathrm{~g} \text { ethanol per day } \\
\text { increase }\end{array}$ & RR I.05 (95\% Cl I.02-1.08) \\
\hline \multicolumn{6}{|l|}{ Smoking } \\
\hline \multirow[t]{2}{*}{$\begin{array}{l}\text { Active } \\
\text { smoking }\end{array}$} & Jones et al $2017^{66}$ & $\begin{array}{l}\text { Cohort study ( } 1815 \\
\text { participants) }\end{array}$ & Increased & $\begin{array}{l}\text { "Ever" smokers vs. "Never" } \\
\text { smokers }\end{array}$ & HR I.I4 (95\% Cl I.03-I.25) \\
\hline & $\begin{array}{l}\text { Macau et al } \\
2015^{68}\end{array}$ & Meta-analysis & Increased & $\begin{array}{l}\text { "Ever" smokers vs "Never" } \\
\text { smokers }\end{array}$ & $\begin{array}{l}6 \text { prospective studies: RR I.II } \\
(1.00-1.25)\end{array}$ \\
\hline \multirow[t]{3}{*}{$\begin{array}{l}\text { Passive } \\
\text { Smoking }\end{array}$} & \multirow[t]{2}{*}{ Johnson $2005^{63}$} & \multirow[t]{2}{*}{ Meta-analysis } & \multirow[t]{2}{*}{ Increased } & \multirow{2}{*}{$\begin{array}{l}\text { Exposure to second hand } \\
\text { smoke in women who had } \\
\text { never smoked vs. no } \\
\text { adequate exposure }\end{array}$} & $\begin{array}{l}\text { All I4 studies: Pooled RR I.68 } \\
(1.33-2.12)\end{array}$ \\
\hline & & & & & $\begin{array}{l}5 \text { studies corrected for more } \\
\text { comprehensive passive smoke } \\
\text { exposure assessment: RR } 2.19 \\
(1.68-2.84)\end{array}$ \\
\hline & $\begin{array}{l}\text { Macau et al } \\
2015^{68}\end{array}$ & Meta-analysis & Increased & $\begin{array}{l}\text { "Ever" exposure to passive } \\
\text { smoking compared with } \\
\text { "never" }\end{array}$ & $\begin{array}{l}5 \text { prospective studies: RR I.16 } \\
(0.62-2.16)\end{array}$ \\
\hline
\end{tabular}


Table 2 (Continued).

\begin{tabular}{|c|c|c|c|c|c|}
\hline $\begin{array}{l}\text { Risk } \\
\text { Factor }\end{array}$ & $\begin{array}{l}\text { Author and } \\
\text { Year }\end{array}$ & Type of Study & $\begin{array}{l}\text { Effect on Risk of } \\
\text { Premenopausal } \\
\text { Breast Cancer }\end{array}$ & Comparator & Magnitude of Risk $(95 \% \mathrm{Cl})$ \\
\hline \multicolumn{6}{|c|}{ Night Shift Work } \\
\hline & $\begin{array}{l}\text { Wegrzyn et al } \\
2016^{70}\end{array}$ & $\begin{array}{l}\text { Analysis of data from } 2 \\
\text { prospective cohort } \\
\text { studies: Nurses' Health } \\
\text { study and Nurses' Health } \\
\text { Study II }\end{array}$ & $\begin{array}{l}\text { NHS: No effect } \\
\text { NHS-II: Increased }\end{array}$ & $\begin{array}{l}\text { NHS: } \geq 30 \text { years of shift } \\
\text { work compared to "never" } \\
\text { NHS-II: } \geq 20 \text { years of shift } \\
\text { work compared to "never" }\end{array}$ & $\begin{array}{l}\text { NHS: HR } 0.95 \text { (0.77-I.I7) } \\
\text { NHS-II: HR } 2.15 \text { (I.23-3.73) }\end{array}$ \\
\hline & $\begin{array}{l}\text { Cordina- } \\
\text { Duverger et al } \\
2018^{73}\end{array}$ & Meta-analysis & Increased & $\begin{array}{l}\text { "Ever" compared to } \\
\text { "Never" having worked } \\
\text { a night shift for } 3 \text { or more } \\
\text { hours between midnight } \\
\text { and } 5 \mathrm{am}\end{array}$ & Pooled OR I.26 (I.06-I.5I) \\
\hline \multicolumn{6}{|c|}{ Hormonal Contraception } \\
\hline & $\begin{array}{l}\text { van den Brandt } \\
\text { et al } 1996^{85}\end{array}$ & Meta-analysis & Increased & $\begin{array}{l}\text { In "Ever" users compared } \\
\text { to "never" users of the } \\
\text { COCP }\end{array}$ & RR I.07 (I.04-I.I0) \\
\hline & & & Increasing & $\begin{array}{l}\text { "Current use" or "Time } \\
\text { since last use" compared to } \\
\text { "never" users of the COCP }\end{array}$ & $\begin{array}{l}\text { Current User: RR I.24 } \\
\text { (I.I5-I.33), I-4y Since last } \\
\text { use: RR I.16 (I.08-I.23), 5-9y } \\
\text { since last use: RR I.07 } \\
(1.02-I .13)\end{array}$ \\
\hline & $\begin{array}{l}\text { Mørch et al } \\
2017^{86}\end{array}$ & $\begin{array}{l}\text { Prospective Cohort study } \\
\text { ( } 1.8 \text { million participants) }\end{array}$ & Increased & $\begin{array}{l}\text { "Ever" use of an LNG-IUS } \\
\left(\text { Mirena }{ }^{\circledR}\right) \text { compared to } \\
\text { "never" used hormonal } \\
\text { contraceptive }\end{array}$ & RR I.2I (I.II-I.33) \\
\hline \multicolumn{6}{|c|}{ Younger age at first pregnancy } \\
\hline & $\begin{array}{l}\text { MacMahon et al } \\
1970^{95}\end{array}$ & $\begin{array}{l}\text { Case-Control ( } 4323 \text { cases, } \\
12,699 \text { controls) }\end{array}$ & Reduced & $\begin{array}{l}\text { Comparing "age at first } \\
\text { birth" sub-groups to } \\
\text { "nulliparous" }\end{array}$ & $\begin{array}{l}\text { Nulliparous: RR I.00, } \leq 20 y: \text { RR } \\
0.50,20-24 y: \text { RR } 0.60,25-29 y: \\
\text { RR } 0.78,30-34 y: \text { RR } 0.94, \\
\geq 35 y: \text { RR I.22 }\end{array}$ \\
\hline \multicolumn{6}{|c|}{ Breastfeeding } \\
\hline & $\begin{array}{l}\text { Collaborative } \\
\text { Group on }\end{array}$ & Meta-analysis & Reduced & $\begin{array}{l}\text { Per } 12 \text { months of } \\
\text { breastfeeding }\end{array}$ & $\begin{array}{l}\text { All breast cancer: } 4.3 \% \\
\text { reduction in RR }\end{array}$ \\
\hline & $\begin{array}{l}\text { Hormonal } \\
\text { Factors in Breast } \\
\text { Cancer, } 2002^{102}\end{array}$ & & & & $\begin{array}{l}\text { Premenopausal breast cancer: } \\
5.1 \% \text { reduction in RR }\end{array}$ \\
\hline
\end{tabular}

Abbreviations: RR, relative risk; OR, overall risk; HR, hazard ratio.

should also accompany conversations regarding reproductive health and hormonal preparations, and take into consideration other modifiable risks and the background individual non-modifiable and iatrogenic $\mathrm{BC}$ risk factors. Increasing understanding of the interactions between genomic and modifiable factors will be vital in providing individualised advice to young women who wish to minimise their personal $\mathrm{BC}$ risk.

\section{Disclosure}

Prof. Ramsey I Cutress reports non-financial support from SECA, outside the submitted work. Dr Ellen R Copson 
reports grants, personal fees from World Cancer Research Fund, non-financial support from SECA, personal fees from AstraZeneca, personal fees from Roche, personal fees from Lilly, personal fees from Pfizer, personal fees from Nanostring, personal fees from Novartis, outside the submitted work. Prof. Cutress and Dr Copson report research funding from World Cancer Research Fund (WCRF UK) as part of the WCRF International grant programme. The authors report no other conflicts of interest in this work.

\section{References}

1. Global Cancer Observatory (GLOBOCAN). Global cancer observatory. Cancer Today- International Agency for Research on Cancer: World Health Organisation; 2018. Available from: https://gco.iarc.fr/today/home. Accessed November 3, 2020.

2. U.S. Department of Health and Human Services, Centers for Disease Control and Prevention and National Cancer Institute. U.S. Cancer Statistics Working Group. U.S. cancer statistics data visualizations tool; June, 2020. Available from: https://gis. cdc.gov/Cancer/USCS/DataViz.html. Accessed November 3, 2020.

3. Cancer Research UK. Breast cancer statistics UK: cancer research UK; 2016. Available from: https://www.cancerresearchuk.org/ health-professional/cancer-statistics/statistics-by-cancer-type /breast-cancer/incidence-invasive\#heading-One. Accessed November 3, 2020.

4. Copson ER, Maishman TC, Tapper WJ, et al. Germline BRCA mutation and outcome in young-onset breast cancer (POSH) a prospective cohort study. Lancet Oncol. 2018;19(2):169-180. doi:10.1016/S1470-2045(17)30891-4

5. Lawson PJ, Flocke SA. Teachable moments for health behavior change: a concept analysis. Patient Educ Couns. 2009;76 (1):25-30. doi:10.1016/j.pec.2008.11.002

6. Senore C, Giordano L, Bellisario C, Di Stefano F, Segnan N. Population based cancer screening programmes as a teachable moment for primary prevention interventions. A review of the literature. Front Oncol. 2012;2:45. doi:10.3389/fonc.2012.00045

7. Gritz ER, Fingeret MC, Vidrine DJ, Lazev AB, Mehta NV, Reece GP. Successes and failures of the teachable moment Cancer. 2006;106(1):17-27. doi:10.1002/cncr.21598

8. Paluch-Shimon S, Cardoso F, Partridge AH, et al. ESO-ESMO 4th international consensus guidelines for breast cancer in young women (BCY4). Ann Oncol. 2020;31(6):674-696. doi:10.1016/j. annonc.2020.03.284

9. Gnerlich JL, Deshpande AD, Jeffe DB, Sweet A, White N, Margenthaler JA. Elevated breast cancer mortality in women younger than age 40 years compared with older women is attributed to poorer survival in early-stage disease. $J$ Am Coll Surg. 2009;208(3):341-347. doi:10.1016/j.jamcollsurg.2008.12.001

10. World Cancer Research Fund. Diet, nutrition, physical activity and breast cancer: a global perspective. World Cancer Research Fund/American Institute for Cancer Research; 2017 (Revised 2018). Available from: dietandcancerreport.org. Accessed November 3, 2020.

11. Howlader N, Altekruse SF, Li CI, et al. US incidence of breast cancer subtypes defined by joint hormone receptor and HER2 status. JNCI. 2014;106(5):dju055-dju. doi:10.1093/jnci/dju055

12. Thomas GA, Leonard RCF. How age affects the biology of breast cancer. Clin Oncol. 2009;21(2):81-85. doi:10.1016/j.clon.20 08.11 .006
13. Narod SA. Breast cancer in young women. Nat Rev Clin Oncol. 2012;9(8):460-470. doi:10.1038/nrclinonc.2012.102

14. Anders CK, Johnson R, Litton J, Phillips M, Bleyer A. Breast cancer before age 40 years. Semin Oncol. 2009;36(3):237-249. doi:10.1053/j.seminoncol.2009.03.001

15. Maas P, Barrdahl M, Joshi AD, et al. Breast cancer risk from modifiable and nonmodifiable risk factors among white women in the United States. JAMA Oncol. 2016;2(10):1295-1302. doi:10.1 001/jamaoncol.2016.1025

16. Brandt J, Garne JP, Tengrup I, Manjer J. Age at diagnosis in relation to survival following breast cancer: a cohort study. World J Surg Oncol. 2015;13(1):33. doi:10.1186/s12957-014-0429-x

17. Collins LC, Marotti JD, Gelber S, et al. Pathologic features and molecular phenotype by patient age in a large cohort of young women with breast cancer. Breast Cancer Res Treat. 2012;131 (3):1061-1066. doi:10.1007/s10549-011-1872-9

18. Lee H-B, Han W. Unique features of young age breast cancer and its management. J Breast Cancer. 2014;17(4):301. doi:10.4048/ jbc.2014.17.4.301

19. Seidler S, Huber D. Breast cancer in young women: implications for clinical practice. Rev Med Suisse. 2020;16(695):1106-1113.

20. Morrison DH, Rahardja D, King E, Peng Y, Sarode VR. Tumour biomarker expression relative to age and molecular subtypes of invasive breast cancer. $\mathrm{Br} J$ Cancer. 2012;107(2):382-387. doi:10.1038/bjc.2012.219

21. Walker R, Lees E, Webb M, Dearing S. Breast carcinomas occurring in young women (<35 years) are different. $\mathrm{Br} J$ Cancer. 1996;74(11):1796-1800. doi:10.1038/bjc.1996.632

22. Lynch HT, Watson P, Conway T, Fitzsimmons ML, Lynch J. Breast cancer family history as a risk factor for early onset breast cancer. Breast Cancer Res Treat. 1988;11(3):263-267. doi:10.1007/BF01807285

23. Lee DS, Yoon S-Y, Looi LM, et al. Comparable frequency of BRCA1, BRCA2 and TP53 germline mutations in a multi-ethnic Asian cohort suggests TP53 screening should be offered together with BRCA1/2 screening to early-onset breast cancer patients. Breast Cancer Res. 2012;14(2):R66. doi:10.1186/bcr3172

24. Gómez-Flores-Ramos L, Álvarez-gómez RM, Villarreal-Garza C, Wegman-Ostrosky T, Mohar A. Breast cancer genetics in young women: what do we know? Mutat Res. 2017;774:33-45. doi:10.1016/j.mrrev.2017.08.001

25. Antoniou AC, Casadei S, Heikkinen T, et al. Breast-cancer risk in families with mutations in PALB2. $N$ Engl $J$ Med. 2014;371 (6):497-506. doi:10.1056/NEJMoa1400382

26. Joslyn SA, Foote ML, Nasseri K, Coughlin SS, Howe HL. Racial and ethnic disparities in breast cancer rates by age: NAACCR breast cancer project. Breast Cancer Res Treat. 2005;92 (2):97-105. doi:10.1007/s10549-005-2112-y

27. Chlebowski RT, Chen Z, Anderson GL, et al. Ethnicity and breast cancer: factors influencing differences in incidence and outcome. J Natl Cancer Inst. 2005;97(6):439-448. doi:10.1093/ jnci/dji064

28. Jack RH, Davies EA, Møller H. Breast cancer and age in black and white women in South East England. Int J Cancer. 2012;130 (5):1227-1229. doi:10.1002/ijc. 26088

29. Copson E, Maishman T, Gerty S, et al. Ethnicity and outcome of young breast cancer patients in the United Kingdom: the POSH study. Br J Cancer. 2014;110(1):230-241. doi:10.1038/bjc.2013.650

30. Rockhill B, Willett WC, Hunter DJ, et al. Physical activity and breast cancer risk in a cohort of young women. $J$ Natl Cancer Inst. 1998;90(15):1155-1160. doi:10.1093/jnci/90.15.1155

31. Wu Y, Zhang D, Kang S. Physical activity and risk of breast cancer: a meta-analysis of prospective studies. Breast Cancer Res Treat. 2013;137(3):869-882. doi:10.1007/s10549-012-2396-7 
32. Hardefeldt PJ, Penninkilampi R, Edirimanne S, Eslick GD. Physical activity and weight loss reduce the risk of breast cancer: a meta-analysis of 139 prospective and retrospective studies. Clin Breast Cancer. 2018;18(4):e601-e12. doi:10.1016/ j.clbc.2017.10.010

33. Chen X, Wang Q, Zhang Y, Xie Q, Tan X. Physical activity and risk of breast cancer: a meta-analysis of 38 cohort studies in 45 study reports. Value Health. 2019;22(1):104-128. doi:10.1016/j.jval.2018.06.020

34. Catsburg C, Kirsh VA, Soskolne CL, et al. Associations between anthropometric characteristics, physical activity, and breast cancer risk in a Canadian cohort. Breast Cancer Res Treat. 2014;145 (2):545-552. doi:10.1007/s10549-014-2973-z

35. Pizot C, Boniol M, Mullie P, et al. Physical activity, hormone replacement therapy and breast cancer risk: a meta-analysis of prospective studies. Eur $J$ Cancer. 2016;52:138-154. doi:10.1016/j.ejca.2015.10.063

36. Friedenreich CM, Cust AE. Physical activity and breast cancer risk: impact of timing, type and dose of activity and population subgroup effects. $\mathrm{Br} \quad J$ Sports Med. 2008;42(8):636-647. doi:10.1136/bjsm.2006.029132

37. Lahmann PH, Friedenreich C, Schuit AJ, et al. Physical activity and breast cancer risk: the European prospective investigation into cancer and nutrition. Cancer Epidemiol Biomarkers Prev. 2007;16(1):36-42. doi:10.1158/1055-9965.EPI-06-0582

38. Hopper JL, Dite GS, MacInnis RJ, et al. Age-specific breast cancer risk by body mass index and familial risk: prospective family study cohort (ProF-SC). Breast Cancer Res. 2018;20 (1):132. doi:10.1186/s13058-018-1056-1

39. Renehan AG, Tyson M, Egger M, Heller RF, Zwahlen M. Bodymass index and incidence of cancer: a systematic review and meta-analysis of prospective observational studies. Lancet. 2008;371(9612):569-578. doi:10.1016/S0140-6736(08)60269-X

40. Van den brandt PA. Pooled analysis of prospective cohort studies on height, weight, and breast cancer risk. Am J Epidemiol. 2000;152(6):514-527. doi:10.1093/aje/152.6.514

41. Bergström A, Pisani P, Tenet V, Wolk A, Adami HO. Overweight as an avoidable cause of cancer in Europe. Int J Cancer. 2001;91 (3):421-430. doi:10.1002/1097-0215(200002)9999:9999<::AIDIJC1053>3.0.CO;2-T

42. Amadou A, Ferrari P, Muwonge R, et al. Overweight, obesity and risk of premenopausal breast cancer according to ethnicity: a systematic review and dose-response meta-analysis. Obes Rev. 2013;14(8):665-678. doi:10.1111/obr.12028

43. Ursin G, Longnecker MP, Haile RW, Greenland S. A meta-analysis of body mass index and risk of premenopausal breast cancer. Epidemiology. 1995;6(2):137-141. doi:10.1097/ 00001648-199503000-00009

44. Schoemaker MJ, Nichols HB, Wright LB, et al. Association of body mass index and age with subsequent breast cancer risk in premenopausal women. JAMA Oncol. 2018;4(11):e181771. doi:10.1001/jamaoncol.2018.1771

45. Michels KB. Longitudinal study on the role of body size in premenopausal breast cancer. Arch Int Med. 2006;166(21):2395.

46. Harris HR, Willett WC, Terry KL, Michels KB. Body fat distribution and risk of premenopausal breast cancer in the nurses' health study II. J Natl Cancer Inst. 2011;103(3):273-278. doi:10.1093/jnci/djq500

47. Rose DP, Vona-Davis L. Interaction between menopausal status and obesity in affecting breast cancer risk. Maturitas. 2010;66 (1):33-38. doi:10.1016/j.maturitas.2010.01.019

48. Vrieling A, Buck K, Kaaks R, Chang-Claude J. Adult weight gain in relation to breast cancer risk by estrogen and progesterone receptor status: a meta-analysis. Breast Cancer Res Treat. 2010;123(3):641-649. doi:10.1007/s10549-010-1116-4

49. Eliassen AH, Colditz GA, Rosner B, Willett WC, Hankinson SE. Adult weight change and risk of postmenopausal breast cancer. JAMA. 2006;296(2):193. doi:10.1001/jama.296.2.193
50. Emaus MJ, Van Gils CH, Bakker MF, et al. Weight change in middle adulthood and breast cancer risk in the EPIC-PANACEA study. Int J Cancer. 2014;135(12):2887-2899. doi:10.1002/ijc.28926

51. Rosner B, Eliassen AH, Toriola AT, et al. Short-term weight gain and breast cancer risk by hormone receptor classification among pre- and postmenopausal women. Breast Cancer Res Treat. 2015;150(3):643-653. doi:10.1007/s10549-015-3344-0

52. Hall IJ, Newman B, Millikan RC, Moorman PG. Body size and breast cancer risk in black women and white women: the Carolina Breast Cancer Study. Am J Epidemiol. 2000;151(8):754-764. doi:10.1093/oxfordjournals.aje.a010275

53. Robinson WR, Tse CK, Olshan AF, Troester MA. Body size across the life course and risk of premenopausal and postmenopausal breast cancer in black women, the Carolina Breast Cancer Study, 1993-2001. Cancer Causes Control. 2014;25 (9):1101-1117. doi:10.1007/s10552-014-0411-5

54. Swanson CA, Coates RJ, Malone KE, et al. Alcohol consumption and breast cancer risk among women under age 45 years. Epidemiology. 1997;8(3):231-237. doi:10.1097/00001648199705000-00001

55. Godinho-Mota JCM, Gonçalves LV, Mota JF, et al. Sedentary behavior and alcohol consumption increase breast cancer risk regardless of menopausal status: a case-control study. Nutrients. 2019;11(8):1871. doi:10.3390/nu11081871

56. Zhang SM, Lee IM, Manson JE, Cook NR, Willett WC, Buring JE. Alcohol consumption and breast cancer risk in the women's health study. Am J Epidemiol. 2007;165(6):667-676. doi:10.1093/aje/kwk054

57. Chen WY, Rosner B, Hankinson SE, Colditz GA, Willett WC. Moderate alcohol consumption during adult life, drinking patterns, and breast cancer risk. JAMA. 2011;306(17):1884. doi:10.1001/jama.2011.1590

58. Jung S, Wang M, Anderson K, et al. Alcohol consumption and breast cancer risk by estrogen receptor status: in a pooled analysis of 20 studies. Int J Epidemiol. 2016;45(3):916-928. doi:10.1093/ ije/dyv156

59. MacMahon B, Trichopoulos D, Cole P, Brown J. Cigarette smoking and urinary estrogens. $N$ Engl $J$ Med. 1982;307 (17):1062-1065.

60. Hiatt RA, Fireman BH. Smoking, menopause, and breast cancer23. J Natl Cancer Inst. 1986;76(5):833-838.

61. Collaborative Group on Hormonal Factors in Breast Cancer. Alcohol, tobacco and breast cancer - collaborative reanalysis of individual data from 53 epidemiological studies, including 58515 women with breast cancer and 95067 women without the disease. Br J Cancer. 2002;87(11):1234-1245. doi:10.1038/sj.bjc.6600596

62. Moore AA, Gould R, Reuben DB, et al. Longitudinal patterns and predictors of alcohol consumption in the United States. Am J Public Health. 2005;95(3):458-464. doi:10.2105/AJPH.2003.019471

63. Johnson KC. Accumulating evidence on passive and active smoking and breast cancer risk. Int $J$ Cancer. 2005;117(4):619-628. doi:10.1002/ijc. 21150

64. Slattery ML, Curtin K, Giuliano AR, et al. Active and passive smoking, IL6, ESR1, and breast cancer risk. Breast Cancer Res Treat. 2008;109(1):101-111. doi:10.1007/s10549-007-9629-1

65. Cathcart-Rake EJ, Ruddy KJ, Johnson RH. Modifiable risk factors for the development of breast cancer in young women. Cancer $J$. 2018;24(6):275-284. doi:10.1097/PPO.0000000000000340

66. Jones ME, Schoemaker MJ, Wright LB, Ashworth A, Swerdlow AJ. Smoking and risk of breast cancer in the Generations Study cohort. Breast Cancer Res. 2017;19(1):118. doi:10.1186/s13058-017-0908-4

67. Morabia A, Bemstein M, Héritier S, Khatchatrian N. Relation of breast cancer with passive and active exposure to tobacco smoke. Am J Epidemiol. 1996;143(9):918-928. doi:10.1093/oxfordjournals.aje.a008835 
68. Macacu A, Autier P, Boniol M, Boyle P. Active and passive smoking and risk of breast cancer: a meta-analysis. Breast Cancer Res Treat. 2015;154(2):213-224. doi:10.1007/s10549015-3628-4

69. Tang L-Y, Chen L-J, Qi M-L, et al. Effects of passive smoking on breast cancer risk in pre/post-menopausal women as modified by polymorphisms of PARP1 and ESR1. Gene. 2013;524(2):84-89. doi:10.1016/j.gene.2013.04.064

70. Wegrzyn LR, Tamimi RM, Rosner BA, et al. Rotating nightshift work and the risk of breast cancer in the nurses' health studies. Am J Epidemiol. 2017;186(5):532-540. doi:10.1093/ aje/kwx140

71. Papantoniou K, Castaño-Vinyals G, Espinosa A, et al. Breast cancer risk and night shift work in a case-control study in a Spanish population. Eur J Epidemiol. 2016;31(9):867-878. doi:10.1007/s10654-015-0073-y

72. Schernhammer ES, Laden F, Speizer FE, et al. Rotating night shifts and risk of breast cancer in women participating in the nurses' health study. JNCI. 2001;93(20):1563-1568. doi:10.1093/jnci/93.20.1563

73. Cordina-Duverger E, Menegaux F, Popa A, et al. Night shift work and breast cancer: a pooled analysis of population-based casecontrol studies with complete work history. Eur J Epidemiol. 2018;33(4):369-379. doi:10.1007/s10654-018-0368-x

74. Hansen J. Night shift work and risk of breast cancer. Curr Environ Health Rep. 2017;4(3):325-339. doi:10.1007/s40572-017-0155-y

75. Nooshinfar E, Safaroghli-Azar A, Bashash D, Akbari ME. Melatonin, an inhibitory agent in breast cancer. Breast Cancer. 2017;24(1):42-51. doi:10.1007/s12282-016-0690-7

76. Heer E, Harper A, Escandor N, Sung H, McCormack V, FidlerBenaoudia MM. Global burden and trends in premenopausal and postmenopausal breast cancer: a population-based study. Lancet Global Health. 2020;8(8):e1027-e37. doi:10.1016/S2214-109X(20) 30215-1

77. Akinyemiju TF, Pisu M, Waterbor JW, Altekruse SF. Socioeconomic status and incidence of breast cancer by hormone receptor subtype. SpringerPlus. 2015;4(1). doi:10.1186/s40064-015-1282-2

78. Winters S, Martin C, Murphy D, Shokar NK. Chapter One breast cancer epidemiology, prevention, and screening. In: Lakshmanaswamy R, editor. Progress in Molecular Biology and Translational Science. Academic Press; 2017:1-32.

79. Pudrovska T, Anikputa B. The role of early-life socioeconomic status in breast cancer incidence and mortality: unraveling life course mechanisms. J Aging Health. 2012;24(2):323-344. doi:10.1177/0898264311422744

80. Kahn JR, Anderson KE. Intergenerational patterns of teenage fertility. Demography. 1992;29(1):39-57. doi:10.2307/2061362

81. Britt KL, Cuzick J, Phillips K-A. Key steps for effective breast cancer prevention. Nat Rev Cancer. 2020;20(8):417-436.

82. Vaz-Luis I, Partridge AH. Exogenous reproductive hormone use in breast cancer survivors and previvors. Nat Rev Clin Oncol. 2018;15(4):249-261. doi:10.1038/nrclinonc.2017.207

83. Vinogradova Y, Coupland C, Hippisley-Cox J. Use of hormone replacement therapy and risk of breast cancer: nested case-control studies using the QResearch and CPRD databases. BMJ. 2020; m3873. doi:10.1136/bmj.m3873

84. Stewart C Contraceptive use among women in England 2018/19, by type and age statista.com; 2019. Available from: https://www statista.com/statistics/573210/contraceptive-use-among-womenby-type-and-age-in-england/. Accessed November 3, 2020.

85. van den Brandt PA, Goldbohm RA; Collaborative Group on Hormonal Contraceptives. Breast cancer and hormonal contraceptives: collaborative reanalysis of individual data on 53297 women with breast cancer and 100239 women without breast cancer from 54 epidemiological studies. Lancet. 1996;347 (9017):1713-1727.
86. Mørch LS, Skovlund CW, Hannaford PC, Iversen L, Fielding S, Lidegaard $\varnothing$. Contemporary hormonal contraception and the risk of breast cancer. $N$ Engl J Med. 2017;377(23):2228-2239. doi:10.1056/NEJMoa1700732

87. Westhoff CL, Pike MC. Hormonal contraception and breast cancer. Am J Obstet Gynecol. 2018;219(2):169.e1-.e4. doi:10.1016/j. ajog.2018.03.032

88. Zolfaroli I, Tarín JJ, Cano A. Hormonal contraceptives and breast cancer: clinical data. Eur J Obstet Gynecol Reprod Biol. 2018;230:212-216. doi:10.1016/j.ejogrb.2018.03.058

89. National Institute for Clinical Excellence. Familial breast cancer guidance. Familial breast cancer overview; 2020. Available from: http://pathways.nice.org.uk/pathways/familial-breast-cancer. Accessed November 3, 2020.

90. Conz L, Mota BS, Bahamondes L, et al. Levonorgestrel-releasing intrauterine system and breast cancer risk: a systematic review and meta-analysis. Acta Obstet Gynecol Scand. 2020;99 (8):970-982. doi:10.1111/aogs.13817

91. Luborsky JL, Meyer P, Sowers MF, Gold EB, Santoro N. Premature menopause in a multi-ethnic population study of the menopause transition. Hum Reprod. 2003;18(1):199-206 doi:10.1093/humrep/deg005

92. Collaborative Group on Hormonal Factors in Breast Cancer. Type and timing of menopausal hormone therapy and breast cancer risk: individual participant meta-analysis of the worldwide epidemiological evidence. Lancet. 2019;394(10204):1159-1168. doi:10.1016/S0140-6736(19)31709-X

93. Derks-Smeets IAP, Schrijver LH, De Die-smulders CEM, et al. Ovarian stimulation for IVF and risk of primary breast cancer in BRCA1/2 mutation carriers. Br J Cancer. 2018;119(3):357-363. doi:10.1038/s41416-018-0139-1

94. Huber D, Seitz S, Kast K, Emons G, Ortmann O. Use of fertility treatments in BRCA1/2 mutation carriers and risk for ovarian and breast cancer: a systematic review. Arch Gynecol Obstet. 2020;302(3):715-720. doi:10.1007/s00404-020-05690-4

95. MacMahon B, Cole P, Lin TM, et al. Age at first birth and breast cancer risk. Bull World Health Organ. 1970;43(2):209-221.

96. Albrektsen G, Heuch I, Hansen S, Kvåle G. Breast cancer risk by age at birth, time since birth and time intervals between births: exploring interaction effects. Br J Cancer. 2005;92(1):167-175. doi:10.1038/sj.bjc. 6602302

97. Nguyen B, Venet D, Lambertini M, et al. Imprint of parity and age at first pregnancy on the genomic landscape of subsequent breast cancer. Breast Cancer Res. 2019;21(1):25. doi:10.1186/ s13058-019-1111-6

98. Dall GV, Hawthorne S, Seyed-Razavi Y, et al. Estrogen receptor subtypes dictate the proliferative nature of the mammary gland. $J$ Endocrinol. 2018;237(3):323-336.

99. Nichols HB, Schoemaker MJ, Cai J, et al. Breast cancer risk after recent childbirth. Ann Intern Med. 2019;170(1):22-30. doi:10.7326/M18-1323

100. Hall IJ, Moorman PG, Millikan RC, Newman B. Comparative analysis of breast cancer risk factors among African-American women and white women. Am J Epidemiol. 2005;161(1):40-51. doi:10.1093/aje/kwh331

101. Ambrosone CB, Higgins MJ. Relationships between breast feeding and breast cancer subtypes: lessons learned from studies in humans and in mice. Cancer Res. 2020;80(22):4871. doi:10.1158/ 0008-5472.CAN-20-0077

102. Collaborative Group on Hormonal Factors in Breast Cancer. Breast cancer and breastfeeding: collaborative reanalysis of individual data from 47 epidemiological studies in 30 countries, including 50302 women with breast cancer and 96973 women without the disease. Lancet. 2002;360(9328):187-195. doi:10.1016/S0140-6736(02)09454-0 
103. Ursin G, Bernstein L, Lord SJ, et al. Reproductive factors and subtypes of breast cancer defined by hormone receptor and histology. $\mathrm{Br} \quad J$ Cancer. 2005;93(3):364-371. doi:10.1038/sj. bjc. 6602712

104. Islami F, Liu Y, Jemal A, et al. Breastfeeding and breast cancer risk by receptor status - a systematic review and meta-analysis. Ann Oncol. 2015;26(12):2398-2407. doi:10.1093/annonc/mdv379

105. World Health Organisation (WHO). Global Strategy for Infant and Young Child Feeding. WHO Nutrition; 2003.

106. National Institute for Health and Care Excellence (NICE). Familial breast cancer: classification, care and managing breast cancer and related risks in people with a family history of breast cancer, Clinical guideline [CG164]. Breast cancer guidance. National Institute for Health and Care Excellence; 2019. Available from: nice.org.uk. Accessed February 2021.

107. Cuzick J, Sestak I, Bonanni B, et al. Selective oestrogen receptor modulators in prevention of breast cancer: an updated meta-analysis of individual participant data. Lancet. 2013;381 (9880):1827-1834. doi:10.1016/S0140-6736(13)60140-3

108. Cuzick J, Sestak I, Cawthorn S, et al. Tamoxifen for prevention of breast cancer: extended long-term follow-up of the IBIS-I breast cancer prevention trial. Lancet Oncol. 2015;16(1):67-75. doi:10.1016/S1470-2045(14)71171-4

109. Lu L, Shi L, Zeng J, Wen Z. Aspirin as a potential modality for the chemoprevention of breast cancer: a dose-response meta-analysis of cohort studies from 857,831 participants. Oncotarget. 2017;8(25).

110. Cao Y, Tan A. Aspirin might reduce the incidence of breast cancer: an updated meta-analysis of 38 observational studies. Medicine (Baltimore). 2020;99(38):e21917. doi:10.1097/ MD.0000000000021917

111. National Institute for Health and Care Excellence (NICE) Clinical Knowledge Summary. Breast cancer - managing family history. Available from: https://cks.nice.org.uk/topics/breast-cancermanaging-fh/management/breast-cancer-managing-fh/. Accessed February 2, 2021.

112. Sturrock RD, Harpwood BJ, London DR, Milward TM, Silman AJ, Sloane JP. Silicone Gel Breast Implants. The National Archives: Medicines Healthcare and Regulatory Agency: Independent Review Group- silicone gel breast implants; 2011. Contract No.: 23/ 11/2020.

113. Lavigne E, Holowaty EJ, Pan SY, et al. Breast cancer detection and survival among women with cosmetic breast implants: systematic review and meta-analysis of observational studies. $\mathrm{Br}$ Med J. 2013;346(apr29 1):f2399. doi:10.1136/bmj.f2399

114. Clemens MW, Jacobsen ED, Horwitz SM. 2019 NCCN consensus guidelines on the diagnosis and treatment of Breast Implant-Associated Anaplastic Large Cell Lymphoma (BIA-ALCL). Aesthet Surg J. 2019;39(Supplement_1):S3-s13. doi:10.1093/asj/sjy331

115. Medicines and Healthcare products Regulatory Agency (MHRA). Breast implants and Anaplastic Large Cell Lymphoma (ALCL); 2017. Available from: https://www.gov.uk/guidance/breastimplants-and-anaplastic-large-cell-lymphoma-alcl. Accessed November 3, 2020.

116. Bright CJ, Reulen RC, Winter DL, et al. Risk of subsequent primary neoplasms in survivors of adolescent and young adult cancer (Teenage and Young Adult Cancer Survivor Study): a population-based, cohort study. Lancet Oncol. 2019;20 (4):531-545. doi:10.1016/S1470-2045(18)30903-3
117. Bhatia S, Robison LL, Oberlin O, et al. Breast cancer and other second neoplasms after childhood Hodgkin's disease. $N$ Engl $J$ Med. 1996;334(12):745-751. doi:10.1056/ NEJM199603213341201

118. Schaapveld M, Aleman BMP, van Eggermond AM, et al. Second cancer risk up to 40 years after treatment for Hodgkin's Lymphoma. $N$ Engl $J$ Med. 2015;373(26):2499-2511. doi:10.1056/NEJMoa1505949

119. Sud A, Thomsen H, Sundquist K, Houlston RS, Hemminki K. Risk of second cancer in Hodgkin Lymphoma survivors and influence of family history. $J$ Clin Oncol. 2017;35 (14):1584-1590. doi:10.1200/JCO.2016.70.9709

120. Travis LB, Hill DA, Dores GM, et al. Breast cancer following radiotherapy and chemotherapy among young women with Hodgkin disease. JAMA. 2003;290(4):465-475. doi:10.1001/ jama.290.4.465

121. Public Health England. Guidance: tests and frequency of testing for women at very high risk. Available from: https://www.gov.uk/gov ernment/publications/breast-screening-higher-risk-women-surveil lance-protocols/tests-and-frequency-of-testing-for-women-at-veryhigh-risk. Accessed January 2021.

122. Colonna S, Curtin K, Johnson E, et al. Family history of breast cancer associated with breast cancer in survivors of Hodgkin Lymphoma. Int J Cancer Clin Res. 2019;6(1). doi:10.23937/ 2378-3419/1410107.

123. Nichols KE, Heath JA, Friedman D, et al. TP53, BRCA1, and BRCA2 tumor suppressor genes are not commonly mutated in survivors of Hodgkin's disease with second primary neoplasms. J Clin Oncol. 2003;21(24):4505-4509. doi:10.1200/JCO.2003.12.042

124. Niehoff NM, Nichols HB, Zhao S, White AJ, Sandler DP. Adult physical activity and breast cancer risk in women with a family history of breast cancer. Cancer Epidemiol Biomarkers Prev. 2019;28(1):51-58. doi:10.1158/1055-9965.EPI-18-0674

125. Tryggvadottir L, Sigvaldason H, Olafsdottir GH, et al. Population-based study of changing breast cancer risk in Icelandic BRCA2 mutation carriers, 1920-2000. J Natl Cancer Inst. 2006;98(2):116-122. doi:10.1093/jnci/djj012

126. Jernström $H$, Lerman $C$, Ghadirian $P$, et al. Pregnancy and risk of early breast cancer in carriers of BRCA1 and BRCA2. Lancet. 1999;354(9193):1846-1850. doi:10.1016/S0140-6736(99)04336-6

127. Ko K-P, Kim SJ, Huzarski T, et al. The association between smoking and cancer incidence in BRCA1 and BRCA2 mutation carriers. Int J Cancer. 2018;142(11):2263-2272. doi:10.1002/ijc.31257

128. Hollands GJ, French DP, Griffin SJ, et al. The impact of communicating genetic risks of disease on risk-reducing health behaviour: systematic review with meta-analysis. BMJ. 2016;352: i1102. doi:10.1136/bmj.i1102

129. Wright CE, Harvie M, Howell A, Evans DG, Hulbert-Williams N, Donnelly LS. Beliefs about weight and breast cancer: an interview study with high risk women following a 12 month weight loss intervention. Hered Cancer Clin Pract. 2015;13(1). doi:10.1186/s13053-014-0023-9

130. Harvie M, Cohen $\mathrm{H}$, Mason $\mathrm{C}$, et al. adherence to a diet and exercise weight loss intervention amongst women at increased risk of breast cancer. Open Obes J. 2010;2:71-80. 


\section{Publish your work in this journal}

Breast Cancer - Targets and Therapy is an international, peer-reviewed open access journal focusing on breast cancer research, identification of therapeutic targets and the optimal use of preventative and integrated treatment interventions to achieve improved outcomes, enhanced survival and quality of life for the cancer patient.

The manuscript management system is completely online and includes a very quick and fair peer-review system, which is all easy to use. Visit http://www.dovepress.com/testimonials.php to read real quotes from published authors.

Submit your manuscript here: https://www.dovepress.com/breast-cancer-targets-and-therapy-journal 